\title{
ERRATUM
}

\section{Erratum to: How do surgeons approach breast cancer surgery in Turkey? A national survey}

\author{
Mustafa Emiroğlu • Abdullah Inal $\cdot$ İsmail Sert $\cdot$ Enver İlhan • \\ Kemal Peker · Mehmet Ali Gulcelik • Hilmi Güngör · \\ Semra Salimoğlu • Didem Can · Hülya Ellidokuz • Cengiz Aydın
}

Published online: 28 November 2013

(C) The Japanese Breast Cancer Society 2013

\section{Erratum to: Breast Cancer}

DOI 10.1007/s12282-013-0500-4

The correct name of the co-author should be "Mehmet Ali Gulcelik', and not "Mehmet Ali Gürçelik', as given in the original publication of the article.

The online version of the original article can be found under doi:10.1007/s12282-013-0500-4.

M. Emiroğlu · S. Salimoğlu · C. Aydın

Department of Surgery, Tepecik Training and Research Hospital, İzmir, Turkey

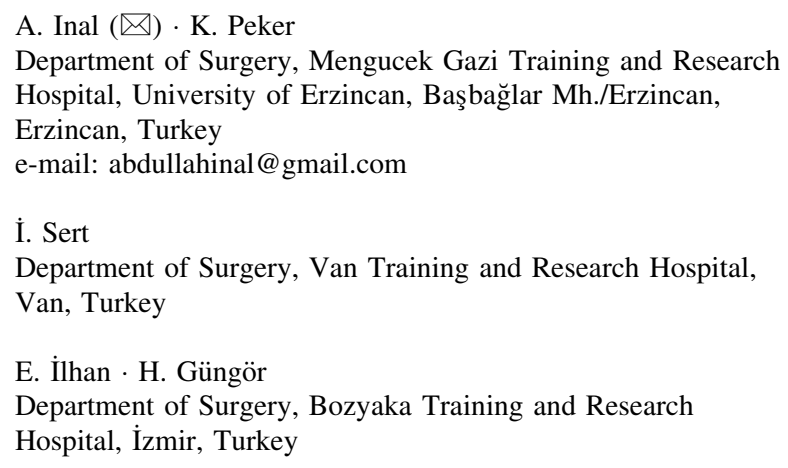

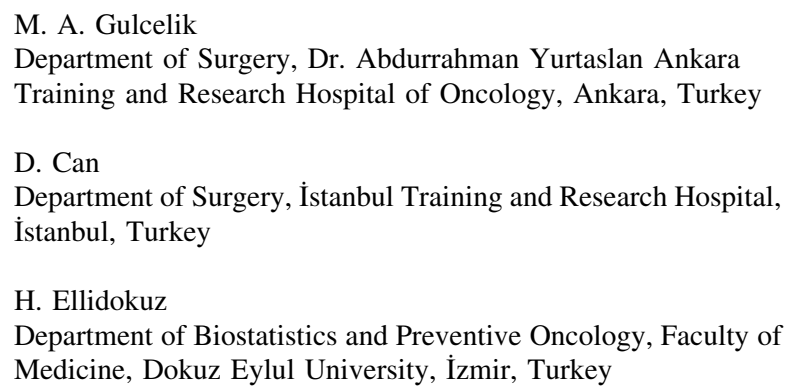

